Hathaway, R. R, and K. D. Woodburn. 1961. Studies on the crown conch, Melongena corona Gmelin. Bull. Mar. Sci. Gulf and Carib. 11: 45-65.

Hutchinson, G. E, 1959. Homage to Santa Rosalia or Why are there so many kinds of animals? Am. Nat. 93: 145-159.

Kohn, A. J. 1959. The ecology of Comes in Hawaii. Ecol. Monogr. 29: 47-90.

Lindeman, R. L. 1942. The trophic-dynamic aspect of ecology. Ecology 23: 399-418.

MacArthur, R, 1955. Fluctuations of animal populations, and a measure of community stability. Ecology 36: 533-536.

_._ and J. W. MacArthur. 1961. On bird species diversity. Ecology 42: 594-598.

Magalhaes, H. 1948. An ecological study of snails of the genus Busycon at Beaufort, North Carolina. Ecol. Monogr. 18: 377-409.

Margalef, R. D. 1958. Information theory in ecology. General Systems 3: 36-71.

Menzel, R. W. 1955. Annotated check-list of the marine fauna and flora of the St. George's SoundApalachee Bay Region, Florida Gulf Coast. Florida State Univ. Ocean. Inst. 61: 1-78.

- and F. E. Nichy. 1958. Studies of the distribution and feeding habits of some oyster predators in Alligator Harbor, Florida. Bull. Mar. Sci. Gulf and Carib. 8: 125-145.

Paine, R. T. 1962. Ecological diversfication in sympatric gastropods of the genus Busyeom. Evolution 16: $515-523$.

- In press. Feeding rate of a predaceous gastropod, Pleuroploca gigantea. Ecology.
Patten, B. C. 1962. Species diversity in net phytoplankton of Raritan Bay. J. Mar. Res. 20: 57-75.

Pilson, M.E.Q. and P. B. Taylor. 1961. Hole-drilling by octopus. Science 134: 1366-1368.

Robertson, R. 1961. The feeding of Strombus and related herbivorous gastropods. Notulae Naturae 343: $1-9$.

Sanders, H. L., E. M. Goudsmit, E. L. Mills, and G. E. Hampson. 1962. A study of the intertidal fauna of Barnstablc Harbor, Massachusetts. Limn. Ocean. 7: 63-79.

Scheltema, R. S. 1961. Metamorphosis of the veliger larvae of Nassarius obsoletus (Gastropoda) in response to bottom sediment. Biol. Bull. 120: 92-109.

Stehouwer, H. 1952. The preference of the slug Aeolidia papillosa (L.) for the sea anemone Metridium senile (L.). Arch. Neerl. Zool.10: 161-170.

Tate, M. W. and R. C. Clelland. 1957. Nonparametric and short-cut statistics. Danville, Ill: Interstate Printers and Publishers, Inc.

Turner, H. J. 1951. Fourth report on Investigations of the Shellfisheries of Massachusetts. Comm. Mass., Dent. Conserv., Div. Mar. Fish.

- 1955. How clam drills capture razor clams. Nautilus 60: 20-22.

- 1958. The effect of nutrition on the color of the callus of Polinices duplicatus. Nautilus 72: 1-3.

Wells, H. W. 1958a. Predation of pelecypods and gastropods by Fasciolaria hunteria (Perry). Bull. Mar. Sci. Gulf and Carib. 8: 152-166.

- 1958b. Feeding habits of Murex fulvescens. Ecology 39: 556-558.

Willcox, J. 1895. The habits of Florida littoral mollusks. Nautilus 8: 79-80.

\title{
COMPARISON OF TEMPERATURE AND MOISTURE RESPONSES OF THE SNAIL GENERA POMATIOPSIS AND ONCOMELANIA
}

\author{
Henry van der Schalie and Lowell L. Getz \\ Museum of Zoology, University of Michigan, Ann Arbor, and Department of Zoology and \\ Entomology, University of Connecticut, Storrs
}

\section{INTRODUCTION}

The relationship between amnicolid snails belonging to the American genus Pomatiopsis and the Oriental genus Oncomelania has been known for a long time. Increased interest in the latter group was stimulated when they were recognized as the hosts for the Oriental blood fluke, Schistosoma japonicum. It was somewhat later that active work on the American Pomatiopsis was initiated, particularly at the close of the war when service men, as well as dogs which had been loaned to the Armed Forces, returned to the continental United States from Pacific regions infected with schistosomiasis. Stunkard (1946), Berry and Rue

\footnotetext{
1 This work was sponsored by the Commission of Parasitic Diseases, Armed Forces Epidemiological Board, and supported by The Office of the Surgeon General, Department of The Army.
}

(1948), Abbott (1948), and others stressed the need for basic studies of amnicolid snails and especially species in the genus Pomatiopsis. Berry and Rue (1948) found that $P$. lapidaria could be infected with the Chinese strain (personal communication) of Schistosoma japonicum; van der Schalie and Basch (unpublished data) found development to the sporocyst stage in one of $25 P$. cincinnatiensis, which had been exposed to miracidia of the Japanese strain of $S$. japonicum. Extensive work has been done on Oncomelania in such centers as the 406th Medical General Laboratory in Japan (Hunter III, Ritchie, Williams, et al.), the W.H.O. Philippine 9 team in Palo, Leyte (Pesigan, Hairston, et al.), and in other laboratories. There is general agreement as to the need better to understand the life history and ecology of the Oncomelania snails. 
Intensive work with both local species of Pomatiopsis ( $P$. lapidaria and $P$. cincinnatiensis) was begun in the laboratory of the senior author about 6 years ago. For reference we were fortunate in having available an excellent study of the amnicolid snails of Michigan by E. G. Berry (1943). In addition, some unusually good colonies of both species of Pomatiopsis are available in the vicinity of Ann Arbor. With this large reserve of local material and with facilities for culturing Oncomelania (only a few specimens of $O$. hupensis were available for use, however), a wide variety of studies has been possible. Several investigations have centered on $P$. cincinnatiensis dealing with its distribution, ecology and life history (van der Schalie and Dundee 1955, van der Schalie and Getz, in press), its morphology (van der Schalie and Dundee 1956), its egg-laying habits (van der Schalie and Walter 1957), and the comparative difference in moisture requirements between the young and adults (van der Schalie and Getz 1961). Likewise, studies of $P$. lapidaria to date centered on its ecology, morphology and distribution (Dundee 1957, van der Schalie and Dundee 1959).

Many difficulties were experienced in culturing species of Oncomelania and Pomatiopsis in the laboratory. While efforts were made to duplicate as nearly as possible the conditions observed in the field for each species, there were no data available to indicate the range of tolerance to variables of such conditions as temperature, moisture of air and substrate, or ability to tolerate drowning or desiccation. It was observed that the species varied in their reactions to the environmental conditions, but few data were available to determine the parameters to ecological conditions for the several species. Without such knowledge it is difficult to culture certain of the species and one cannot interpret behavior in an effort to compensate for unfavorable conditions. $P$. cincinnatiensis proved to be most difficult to maintain; hence it received more attention (van der Schalie and Getz 1961 and in press). It was found that $P$. lapidaria was most similar in its response to moisture conditions to the 4 species of Oncomelania. It is also similar in that it is a biennial species, while $P$. cincinnatiensis has been shown to be an annual. In the experiments that follow, the data indicate several striking differences between the ecological tolerances of the 2 species of Pomatiopsis; it is also evident that each of the species of Oncomelania and Pomatiopsis tested has rather definite tolerance ranges which tend to identify the species. In some cases, the optima are different from what one might expect if the species is considered with respect to its normal zoogeographic range.

\section{Temperature Responses Preferences}

A temperature gradient was established using equipment similar to that described by Getz (1959). The apparatus consisted of a trough (made of $1 / 10$ inch tinned-copper) $1 \times 1 \times 24$ inch, with a $1 \times 1 \times 2$ inch water-tight compartment at each end. Each compartment was provided with an inlet and an outlet tube. The bottom of the trough was covered with wet blotter paper marked into 24 sections of 1 inch. A glass cover, held in place by a series of flanges, was placed 3/8 inch above the floor to keep the snails on the same plane so as to avoid vertical temperature gradients. The top of the trough was covered with a piece of plate glass which was in turn covered by opaque paper. Nine thermister thermometers were taped to the bottom of the trough (under sections $1,3,6,9,12,15,18,21$, and 24) to determine temperatures along the trough. The entire trough was packed in a box of cotton (to insulate it against temperature influences from the outside).

To create a gradient, water heated by passing through a coil in a beaker of boiling water was circulated through the compartment at one end, while water cooled by passage through coils in a chest of crushed ice circulated through the other. The temperature of water going through each terminal compartment was varied by increasing or decreasing the rate of flow through each coil and compartment until a uniform gradient between suitable extremes was produced along the experimental chamber. Once such a gradient was attained $\left(36-6^{\circ} \mathrm{C}\right)$, an experiment was conducted by placing snails of one species in the 3 central sections. The 2 glass covers were then put back in place and the box was darkened to avoid any possible influence of light. After 6 hours the numbers of snails in each section were recorded. Two species of Pomatiopsis, $P$. lapidaria and $P$. cincinnatiensis, and 4 species of Oncomelania, $O$. quadrasi, $O$. nosophora, $O$. formosana, and $O$. hupensis, were tested. The mean temperatures preferred by the 6 species varied from $21^{\circ} \mathrm{C}$ for $P$. cincinnatiensis and $O$. hupensis to $26^{\circ} \mathrm{C}$ for $O$. quadrasi (Figure 1). The range of temperature selection was mainly between $12^{\circ} \mathrm{C}$ and $30^{\circ} \mathrm{C}$ for most species excepting a few isolated snails in the lower ranges; $O$. quadrasi showed a second peak of distribution at $18^{\circ} \mathrm{C}$, probably indicating that the individuals in question were chilled to a point where they were unable to move back toward the warmer end of the gradient. This inability to 

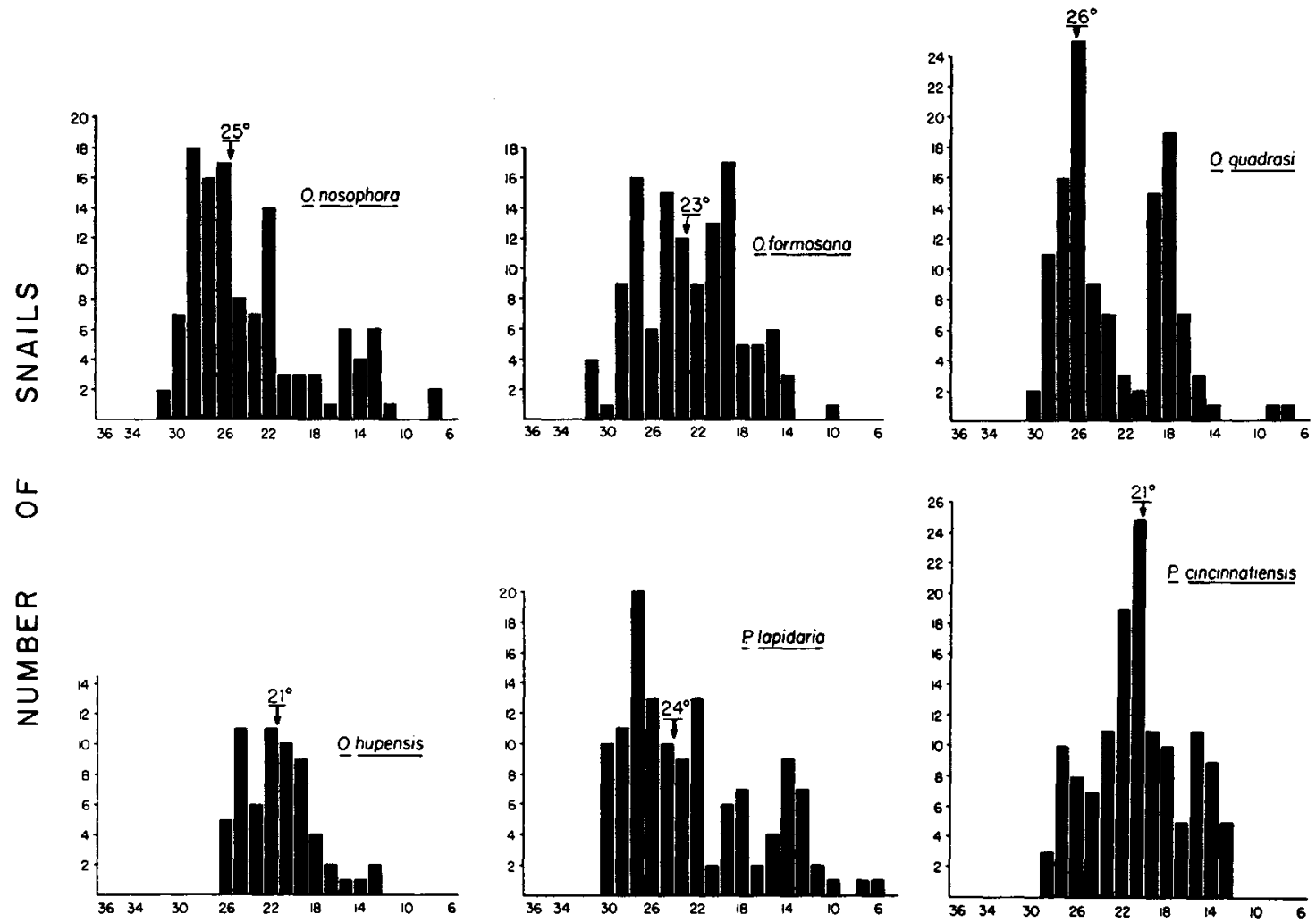

TEMPERATURE

G R A DIEN T

$\left({ }^{\circ} \mathrm{C}\right)$

FIG. 1. Temperature preferences of Oncomelania and Pomatiopsis. Distribution of individuals after 6 hours in a temperature gradient of $36^{\circ} \mathrm{C}-6^{\circ} \mathrm{C}$. The arrow indicates the mean temperature preferred.

move was confirmed by using another, more gradual gradient, ranging between $17^{\circ} \mathrm{C}$ and $33^{\circ} \mathrm{C}$, thus giving the snails a chance to retreat before becoming immobilized. O. quadrasi in both tests was aligned between $20^{\circ} \mathrm{C}$ and $30^{\circ} \mathrm{C}$, with a mean of $26^{\circ} \mathrm{C}$ (Figs. 1 and 2). O. hupensis also showed a somewhat restricted range of temperature preference. This observation of restriction in range may be related in part to fewer data; a rather definite avoidance of temperatures above $26^{\circ} \mathrm{C}$ appears to occur, however. Although the remaining species all had a similar range of temperature preferences, fewer $P$. cincinnatiensis moved above $28^{\circ} \mathrm{C}$ than did the other species, while $O$. formosana appeared to avoid temperatures below $14^{\circ} \mathrm{C}$ to a greater extent.

\section{Tolerances}

\section{Low temperature}

A measure for the tolerance of low temperatures was obtained by 2 methods: (1) a short exposure to extremely low temperature $\left(-5^{\circ} \mathrm{C}\right.$ and $\left.-7^{\circ} \mathrm{C}\right)$, and (2) a longer exposure to temperatures of around $0^{\circ} \mathrm{C}$ and of $5^{\circ} \mathrm{C}$. In the first experiment 50 snails of each of the 5 species used were placed on
3 layers of wet filter paper in a $15 \mathrm{~cm}$ petri dish and the dish was placed in a freezer at $-5^{\circ} \mathrm{C}$ for 3 hours. One day later the number of snails still alive, in decreasing order of tolerance, were as follows: $P$. lapidaria, $17 ; P$. cincinnatiensis, 17 ; O. nosophora, 14; O. formosana, 12; O. quadrasi,

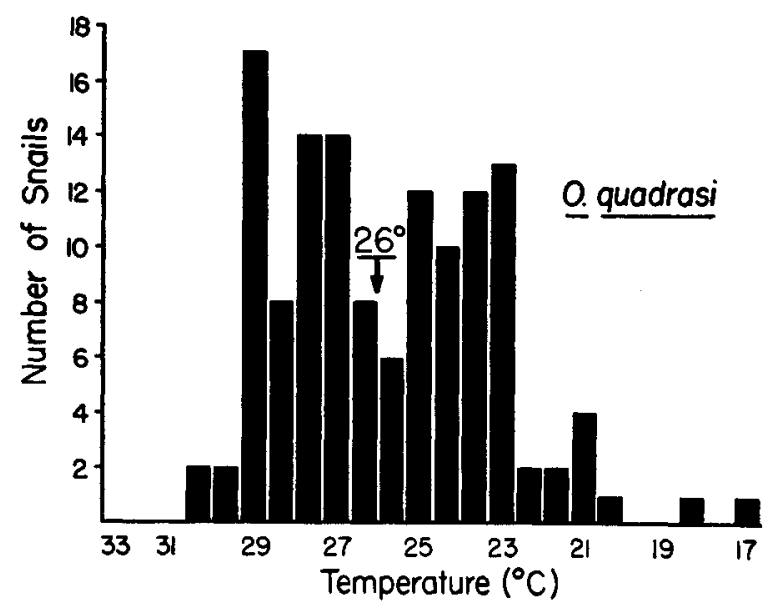

FIG. 2. Temperature preferences of Oncomelania quadrasi at a gradient more gradual than that used in Fig. 1, after 6 hours. The arrow indicates the mean temperature preferred. 
5. A 3-hour exposure to $-7^{\circ} \mathrm{C}$ resulted in the deaths of all individuals of each species tested.

For longer exposure to low temperature, 50 individuals of each of the 6 species were placed in a petri dish, as above, and maintained at $-2^{\circ} \mathrm{C}$ to $+1^{\circ} \mathrm{C}$ for 120 days. In this test, again, $P$. lapidaria was best, and $O$. quadrasi least, able to tolerate the low temperature (Figure 3). A similar procedure, using 5 species, was followed to determine survival at $5^{\circ} \mathrm{C}$. During this experi-

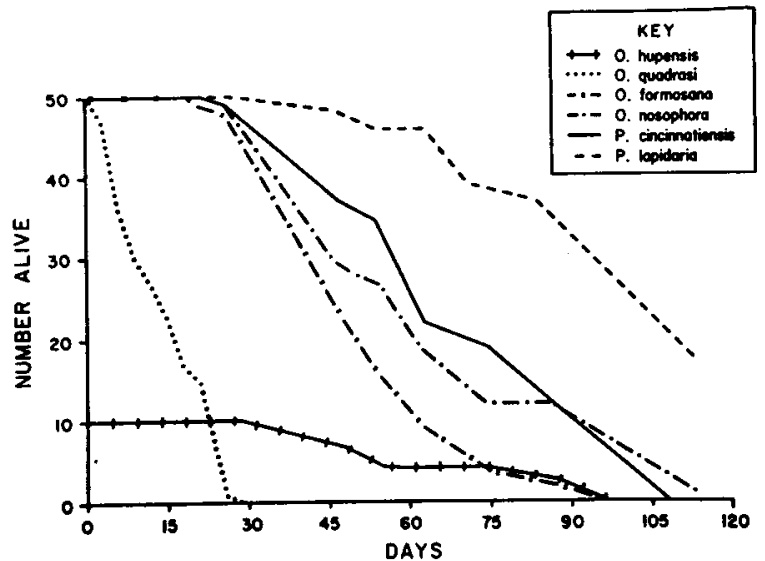

Fig. 3. Survival in days of Oncomelania and Pomatiopsis maintained at a temperature fluctuating between $-2^{\circ} \mathrm{C}$ and $+1^{\circ} \mathrm{C}$.

ment, the filter paper lining the bottom of the petri dish was replaced and the dishes washed once a week. These dishes were inspected periodically for 40 days; the numbers of snails still alive at the end of this time, in decreasing order of tolerance, were as follows: $P$. lapidaria, $50 ; O$. formosana, 50 ; O. nosophora, 48; $P$. cincinnatiensis, 45; $O$. quadrasi, 28.

It appears from these tests that $O$. quadrasi is markedly less able than the other species to tolerate low temperatures, while $P$. lapidaria is at the other end of the scale.

\section{High temperature}

The tolerance of high temperatures of 5 snail species was determined by 2 methods: (1) short exposures to high temperatures $\left(34^{\circ} \mathrm{C}\right.$ to $\left.48^{\circ} \mathrm{C}\right)$, and (2) longer exposures to less extreme temperatures $\left(30^{\circ} \mathrm{C}\right.$ and $\left.35^{\circ} \mathrm{C}\right)$. To determine tolerance for short exposures at high temperatures, 5 individuals of each species were placed on wet filter paper in a stendor dish (with covers in place). For each species 15 such dishes were placed in an oven and the temperature set at $34^{\circ} \mathrm{C}$. The animals were maintained at that temperature for 30 minutes, then 1 dish was removed and the oven temperature raised to $35^{\circ} \mathrm{C}$. This temperature was again maintained for 30 minutes and another dish removed. The procedure of raising the temperature by $1{ }^{\circ} \mathrm{C}$ and removing a dish every half hour was continued up through to $48^{\circ} \mathrm{C}$. The snails were checked 18 hours later and again after 30 hours to determine the number still alive (Table I).

Table I. Survival of Oncomelania and Pomatiopsis snails 18 and 30 hours after cumulative exposures to temperatures increased by $1^{\circ} \mathrm{C}$, from $34^{\circ} \mathrm{C}$ to $48^{\circ} \mathrm{C}$, every 30 minutes

\begin{tabular}{|c|c|c|c|c|c|c|c|c|c|c|}
\hline \multirow{3}{*}{$\begin{array}{l}\text { Hours after } \\
\text { exposure }\end{array}$} & \multicolumn{10}{|c|}{ NUMBER OF ANAILS OUT OF 5 SURVIVING AFTER EXPOBURE } \\
\hline & \multicolumn{2}{|c|}{$\begin{array}{c}o . \\
\text { quadrasi }\end{array}$} & \multicolumn{2}{|c|}{$\begin{array}{c}O . \\
\text { nosophora }\end{array}$} & \multicolumn{2}{|c|}{$\begin{array}{c}0 . \\
\text { formosana }\end{array}$} & \multicolumn{2}{|c|}{$\begin{array}{l}P . \text { cincin- } \\
\text { natiensis }\end{array}$} & \multicolumn{2}{|c|}{$\underset{\text { lapidaria }}{P .}$} \\
\hline & 18 & 30 & 18 & 30 & 18 & 30 & 18 & 30 & 18 & 30 \\
\hline Temperafure ${ }^{\circ} \mathrm{C}$ & & & & & & & & & & \\
\hline $40^{*} \ldots \ldots \ldots$ & 5 & 5 & 5 & 5 & 5 & 5 & $\mathbf{5}$ & 5 & $\mathbf{5}$ & 5 \\
\hline 41. . & 5 & 4 & 5 & 5 & 5 & 5 & 5 & 4 & 4 & 2 \\
\hline 42. & $\mathbf{5}$ & 4 & 5 & 5 & 5 & 5 & 4 & 2 & 2 & 0 \\
\hline $43 \ldots$ & 3 & 2 & 5 & 5 & 5 & 5 & 3 & 2 & 1 & 0 \\
\hline $44 \ldots \ldots$ & 2 & 0 & 3 & 3 & 4 & 4 & 2 & 1 & 1 & 0 \\
\hline $45 \ldots \ldots$ & 3 & 2 & 3 & 1 & 2 & 1 & 0 & 0 & 0 & 0 \\
\hline $46 \ldots \ldots$ & 0 & 0 & 2 & 0 & 2 & 1 & 0 & 0 & 0 & 0 \\
\hline $47 \ldots \ldots$ & 0 & 0 & 0 & 0 & 0 & 0 & 0 & 0 & 0 & 0 \\
\hline $48 \ldots \ldots$ & 0 & 0 & 0 & 0 & 2 & 0 & 0 & 0 & 0 & 0 \\
\hline
\end{tabular}

* No mortality between $34^{\circ} \mathrm{C}$ and $40^{\circ} \mathrm{C}$, inclusive.

The onset of mortalities ranged between $41^{\circ} \mathrm{C}$ and $44^{\circ} \mathrm{C}$ for different species, total mortalities occurred between $44^{\circ} \mathrm{C}$ and $48^{\circ} \mathrm{C}$. $P$. lapidaria was least able to tolerate higher temperatures of the species examined. In the order of the least to the greatest, the relative ability of the remaining species to tolerate high temperatures was recorded as follows: $P$. cincinnatiensis, $O$. quadrasi, $O$. nosophora, and $O$. formosana. O. formosana was only slightly more tolerant than $O$. nosophora.

Tolerance to longer exposures at $30^{\circ} \mathrm{C}$ and $35^{\circ} \mathrm{C}$ was also determined. Fifty individuals of a species were placed in a petri dish, as in previous tests. The filter paper was changed and the dishes washed at weekly intervals. The dishes were placed in constant temperature chambers and inspected periodically to determine the number of animals still alive. O. formosana was markedly more tolerant to prolonged high temperature $\left(35^{\circ} \mathrm{C}\right)$ than any of the other species tested (Figure 4). While somewhat more tolerant than the remaining species, $O$. nosophora was considerably less so than $O$. formosana. Both $P$. lapidaria and $P$. cincinnatiensis are relatively intolerant to high temperatures, $P$. lapidaria slightly less so than $P$. cincinnatiensis. $O$. quadrasi appears intermediate between the Pomatiopsis and the other Oncomelania in ability to tolerate prolonged high temperatures (Fig. 4). Tests at $30^{\circ} \mathrm{C}$ for the 4 less resistant species confirmed this order of longevity (Figure 5). 


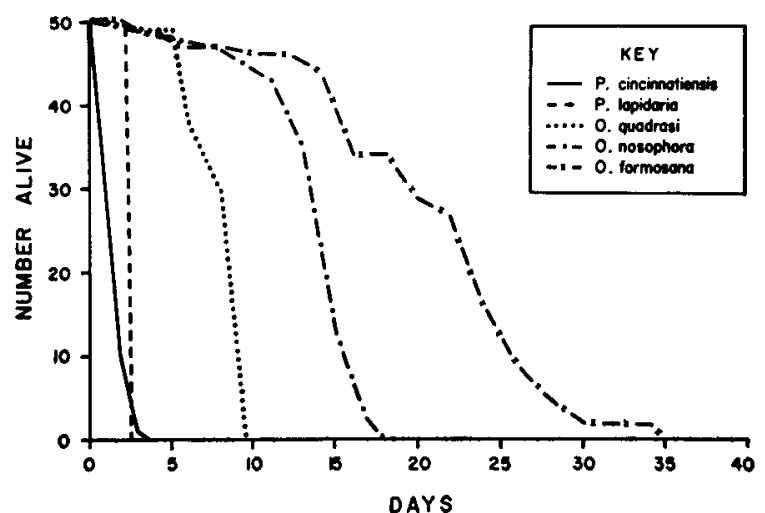

Fig. 4. Survival in days of Oncomelania and Pomatiousis maintained at a temperature of $35^{\circ} \mathrm{C}$.

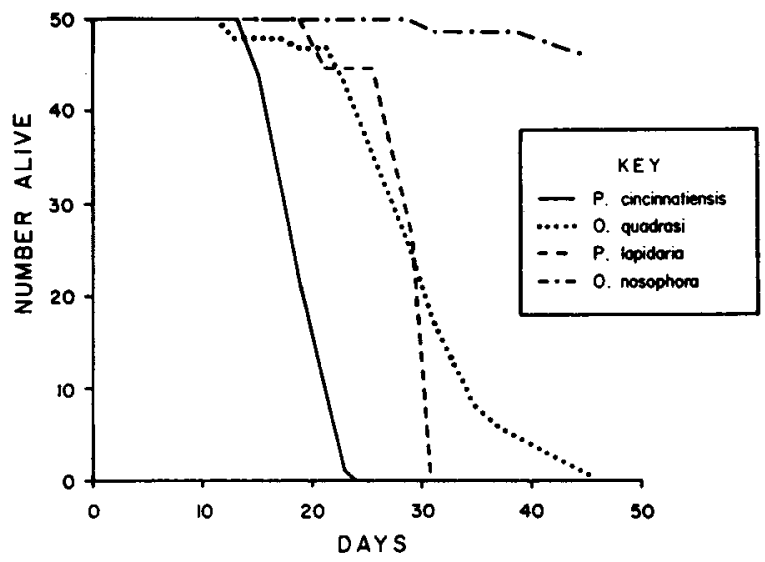

Fig. 5. Survival in days of Oncomelania and Pomatiopsis maintained at a temperature of $30^{\circ} \mathrm{C}$.

\section{Movement}

Data were obtained on 10 individuals of each species; 2 snails at a time were placed in the center of a dry petri dish. The dish, which had been previously conditioned to the temperature used in the experiment for at least $30 \mathrm{~min}$, was placed in a constant temperature cabinet for $10 \mathrm{~min}$. The snails were then removed and talc sprinkled into the dish to reveal the trails left by the snails. These trails were measured with dividers. The same individuals were exposed, in sequence, to temperatures of $5,10,15,20,25,30$, and $35^{\circ} \mathrm{C}$. The temperature chambers were darkened and all had relative humidities of 80 to $85 \%$ except the $35^{\circ} \mathrm{C}$ chamber, which had a relative humidity of $95 \%$. Between the testing periods the snails were placed in distilled water $\left(25^{\circ} \mathrm{C}\right)$ for 5 minutes and the shells dried with a cloth before the start of the next trial.

Of the 6 species tested, all except $P$. cincinnatiensis displayed the same general pattern (Figures 6 and 7 ). In the other 5 species little movement occurred up through $20^{\circ} \mathrm{C}$ with most movement taking place at $25^{\circ} \mathrm{C}$, while at 30 and $35^{\circ} \mathrm{C}$

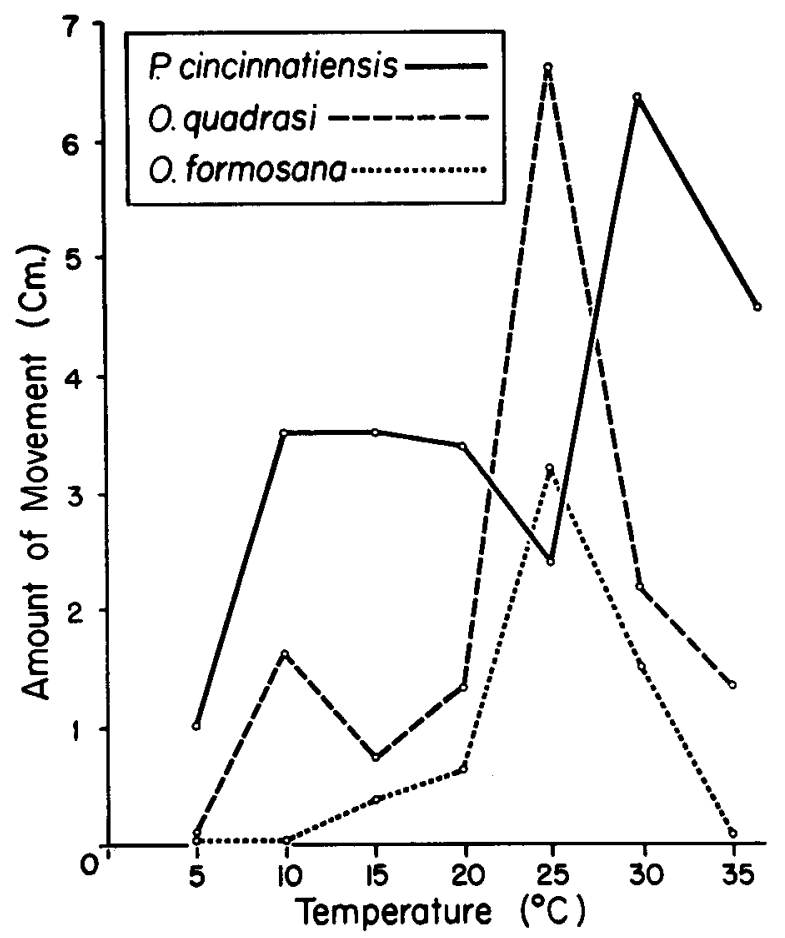

Fic. 6. Movement in relation to temperature. Average distances covered by Oncomelania and Pomatiopsis (10 individuals each for $10 \mathrm{~min}$ ) under exclusion of light.

movement dropped off. $P$. cincinnatiensis had a wider range. It displayed a considerable amount of movement at temperatures as low as $10^{\circ} \mathrm{C}$; its greatest movement was recorded at $30^{\circ} \mathrm{C}$ and it was still high at $35^{\circ} \mathrm{C}$. This species and also $O$. quadrasi showed greater activity than the others.

\section{Moisture Responses Preferences}

To determine preferences for substrate moisture the snails were placed on a gradient ranging from saturation to approximately $20 \%$ of saturation. Such a gradient was established by placing 15 $(1 \mathrm{I} / 4 \times 1$ inch) pads (10 thicknesses of paper toweling) in a long tin box ( $24 \times 1 \times 1$ inch $)$; a gap of approximately $1 / 3$ inch was left between the pads. To establish a moisture gradient, 10 drops of water were placed on the center pad and the amount increased by 5 drops per pad, progressively, toward both ends. This method established a gradient of 10 through 45 drops from the center to each end. The resulting percentages of saturation ranged from approximately 100 at each end to 20 at the middle. Five individuals of each of the 6 species tested were placed on each pad and the box was covered with a glass plate sealed with petrolatum; a dark cloth cover eliminated the possible influence of light. After 24 hours the distribution of the snails on the pads was recorded. 


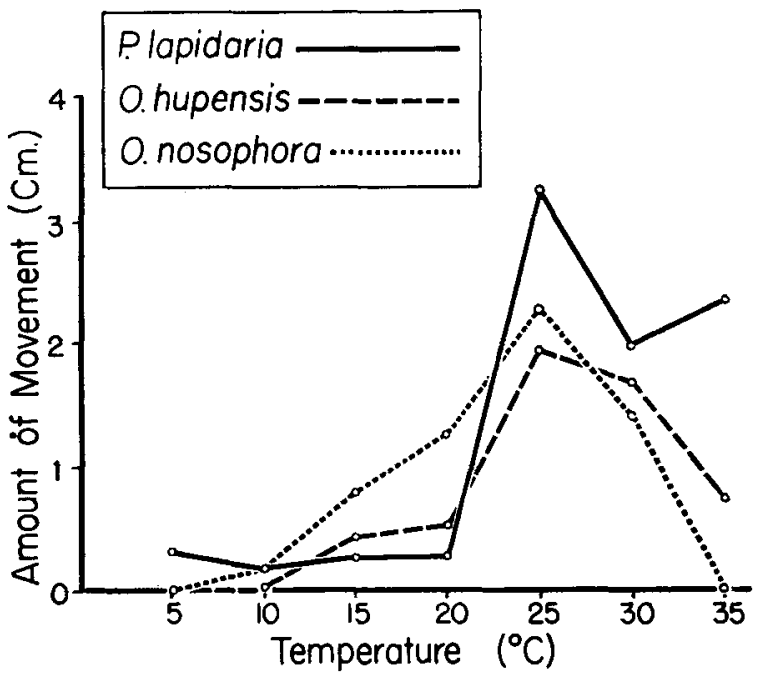

FIG. 7. Movement in relation to temperature. Average distances covered by Oncomelania and Pomatiopsis (10 individuals each for $10 \mathrm{~min}$ ) under exclusion of light.

Since the method of establishing a moisture gradient was rather crude, the data have been used to compare the moisture preferences of the 6 species rather than to obtain absolute preferences for each species. All 6 species avoided the saturated pad; O. quadrasi, O. hupensis, and P. lapidaria appeared to be equally distributed over the remainder of the gradient while the remaining 3 species appeared to avoid the moist half of the gradient (Figure 8 ). $P$. cincinnatiensis had the most narrow range of preference and also tended to avoid the higher moisture conditions more than did any other species. O. hupensis had the widest spread over the gradient. All species tended to avoid the $100 \%$ pads (those $P$. cincinnatiensis that were found on the $100 \%$ pads probably represented individuals that encountered the end of the trough and had not yet reoriented themselves); the others also were distributed in a way that indicated an avoidance of the higher moisture conditions.

\section{Tolerances}

Immersion

All 6 species were tested. Two individuals of a given species were placed in a one dram vial closed with a metal cap punctured by 8 small holes. The vials were filled with distilled water and then immersed in a shallow dish of distilled water at $27^{\circ} \mathrm{C}$. Ten individuals were utilized for $O$. formosana and $O$. hupensis and 30 for all other species. The average survival times in hours, arranged in the order of increasing longevity, are as follows: $P$. cincinnatiensis, $65 ; P$. lapidaria, 85 ; O. nosophora, 130 ; O. quadrasi, 140 ; O. hupensis, 140; O. formosana, 150.

In addition to the above experiment, 2 others were made to determine differences between $P$. lapidaria and $P$. cincinnatiensis. The first consisted of placing 30 individuals of each species in vials as described above, but maintained at $0^{\circ} \mathrm{C}$ instead of $27^{\circ} \mathrm{C}$.

$P$. lapidaria had an average survival time of approximately 500 hours, while $P$. cincinnatiensis survived only 365 hours. In the second experiment, one individual of each species was placed in a corked, $1 / 4$-dram vial of distilled water at $27^{\circ} \mathrm{C}$. Air bubbles were eliminated with a small pin. Twenty individuals of each species were utilized. The survival times were 50 hours for $P$. lapidaria and 20 hours for $P$. cincinnatiensis.

There is, therefore, a marked difference in the ability of the genera Pomatiopsis and Oncomelania to withstand immersion in water; all 4 species of the latter are more tolerant of submergence

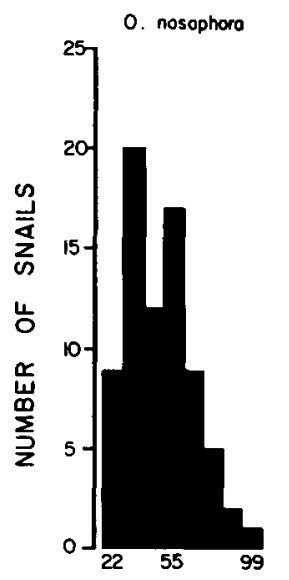

o formosono

0 . hupensis

P. lapidaria

P. cincinnatiensis
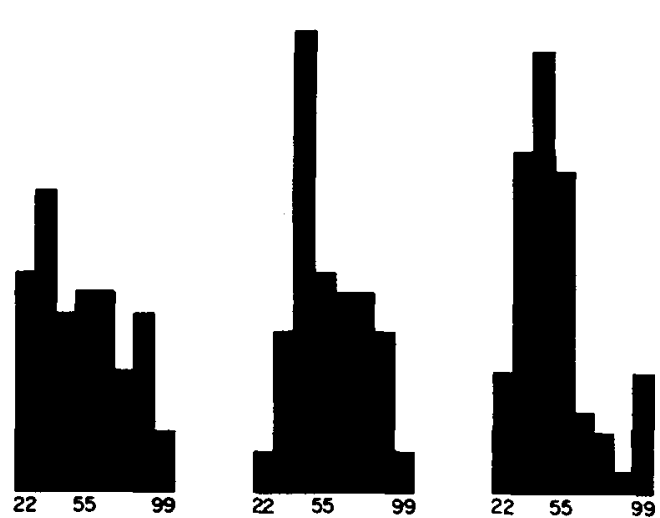

SUBSTRATE MOISTURE (PERCENTAGE OF SATURATION)

FIG. 8. Substrate moisture preferences of Oncomelania and Ponatiopsis. Distribution after 24 hours, under exclusion of light. 
than either of the former. $P$. cincinnatiensis is much less resistant to drowning than is $P$. lapidaria.

\section{Desiccation}

Two methods of desiccation were used on the 5 species of snails tested at a constant temperature of $25^{\circ} \mathrm{C}$. (1) Fifty snails of each species were placed in a petri dish in which dry filter paper was used as a desiccant. The dish was then maintained at a relative humidity of 30 to $35 \%$. The snails were examined daily to determine the number that remained alive; the specimens judged living were those that showed movement of viscera or heart. (2) Ten males and 10 females of each species, in an open 9-cm petri dish (no filter paper), were placed in a desiccating chamber with 0 to $5 \% \mathrm{RH}$. They were weighed at frequent intervals to determine the rate of desiccation.

Both experiments indicate the order of tolerance to desiccation to be, from least to greatest, as follows: $P$. cincinnatiensis, $O$. quadrasi, $P$. lapidaria, $O$. formosana, and $O$. nosophora (Figures 9-11). The deaths of the last survivors among the first 4 species tested in the first series ranged from 6 to 30 days while some $O$. nosophora were still alive on the $42 \mathrm{nd}$ day. In the 2 nd series, loss in body weight on the last day of observation (7th) ranged from 40 (females) and 60 (males) \%, approximately, to more than $95 \%$. In Oncomelania the rate of desiccation was greater for the males than females, up to the 4th day in O. quadrasi and $O$. formosana, and increasingly the 5 th to 7 th day in $O$. nosophora (Figures 10 and 11 ); there was no sexual difference in the rates of desiccation of $P$. lapidaria or $P$. cincinnatiensis.

\section{Movement}

Relative humidities of $95,85,75,65$, and $25 \%$ (at $26^{\circ} \mathrm{C}$ ) were established in covered aquaria by

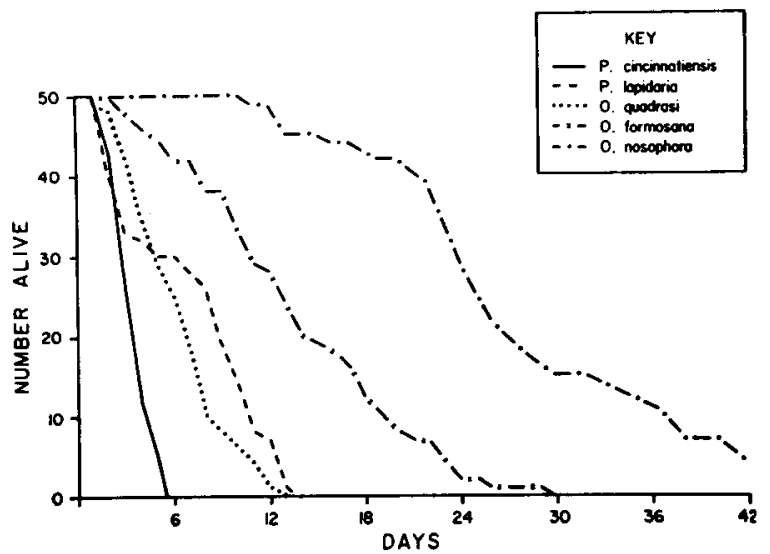

FIg. 9. Tolerance to desiccation. Survival of Oncomelania and Pomatiopsis in days at a relative humidity of $30-35 \%$ at $25^{\circ} \mathrm{C}$.

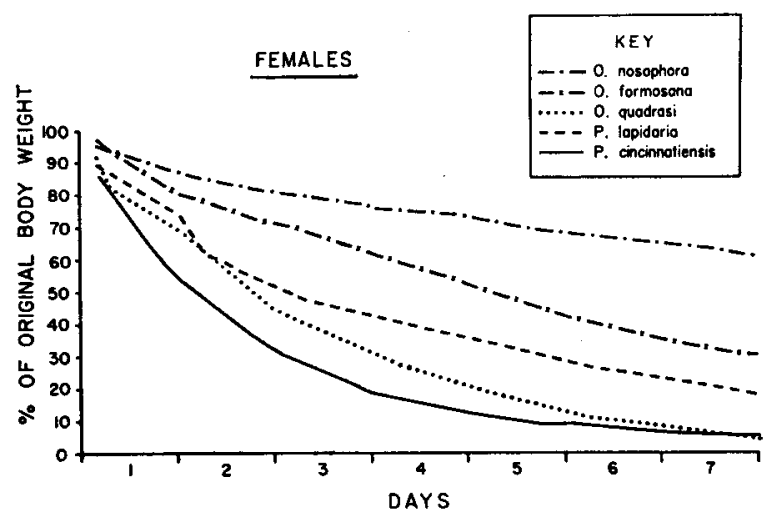

FIG. 10. Tolerance to desiccation. Loss of weight of female Oncomelania and Ponnatiopsis at $0-5 \%$ relative humidity at $25^{\circ} \mathrm{C}$.

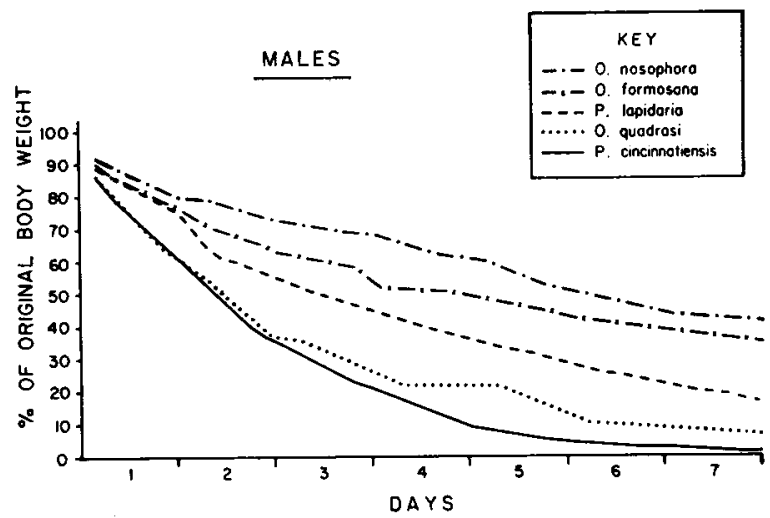

Fig. 11. Tolerance to desiccation. Loss of weight of male Oncomelania and Pomatiopsis at $0-5 \%$ relative humidity at $25^{\circ} \mathrm{C}$.

the use of salt solutions. Humidities were checked with Serdex laboratory hygrometers. Two snails were placed in the center of a clean $9-\mathrm{cm}$ petri dish and the dish placed on a wire floor above the salt solution in the aquaria. A plate glass cover (sealed with petrolatum) was opened only wide enough to insert the dish so that the air in the chamber would not be influenced too greatly by the room air. After the cover was replaced the entire aquarium was covered with an opaque cloth. Each trial lasted $10 \mathrm{~min}$. The movement of 10 individuals ( 5 males and 5 females) of each species was determined for each of the above humidities. The amount of movement was measured by powdering talc into the bottom of the dish at the end of a run. The slime deposit marking each snail's trail thus became visible and was measured with dividers.

To interpret the data relating to movement the following assumptions were made concerning the behavior of these snails. At the higher, favorable humidities individuals will display a moderate amount of movement. As the humidity decreases a percentage is reached that is unfavorable. At 
that point the snail is stimulated and begins moving about; the humidity is still high enough, however, so as not to hamper movement. Hence, one would expect the greatest amount of movement at the point at which the humidity becomes unfavorable. At lower humidities stimulation may also take place, but the animal is less able to move and less movement occurs. Eventually a point is reached at which the animals withdraw into their shells and become inactive.

The results of these tests indicate that the 6 species fall into 2 groups (Figure 12). The first

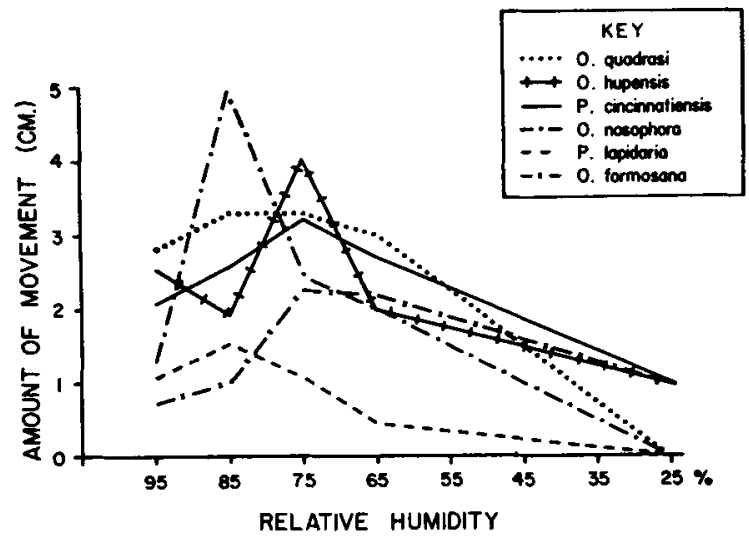

FIG. 12. Movement in relation to humidity. Average distances covered by Oncomelania and Pomatiopsis (10 individuals each for $10 \mathrm{~min}$ ) under exclusion of light.

group, comprising $O$. nosophora, $O$. quadrasi, and $P$. lapidaria, has a more restricted tolerance range; a relative humidity of $85 \%$ already appears to be unfavorable, as maximum movement takes place at that range; activity then falls until no movement occurs at $25 \%$. The other group, $P$. cincinnatiensis, $O$. hupensis, and $O$. formosana, is not yet adversely affected by humidities of $85 \%$; the greatest movement occurs at $75 \%$. There was still considerable movement at the lower limit of the experiment $(25 \%)$. These 3 species, therefore, appear to be more tolerant to lower humidities.

\section{Comparison of Respiratory Systems}

It was found earlier (van der Schalie and Getz 1961) that there appeared to be a relationship between development of the gill system (number of gill filaments) and the moisture requirements of young and adult $P$. cincinnatiensis. In the younger, smaller individuals there were more gill filaments per unit of body mass than in the larger ones. Since the larger animals were found to require less moisture, it was assumed that there was a transfer from gill to pulmonary respiration in this species, the change coming about as individuals approach adult size.
Since there were marked differences in the moisture requirements of the species of Oncomelania and Pomatiopsis, a study was made of the gill structure of these species to see if such differences might be related in part to their mode of respiration.

Gills were dissected from individuals of all 6 species. The number of gill filaments was counted and the shape of the gills also noted. In dissection the snails were relaxed with nembutal, fixed in Bouin's solution (which also removed the shell), and the animals preserved in 50\% alcohol. The results are given in Table II.

TABLE II. Number of gill filaments in relation to size in Oncomelania and Pomatiopsis

\begin{tabular}{|c|c|c|c|c|}
\hline \multirow[b]{2}{*}{ Species } & \multicolumn{2}{|c|}{ INDIYJDUALS } & \multicolumn{2}{|c|}{ AYERAGE NUMBER OF } \\
\hline & Number & Size in $\mathrm{mm}$ & $\begin{array}{l}\text { Pairs gill } \\
\text { filaments }\end{array}$ & $\begin{array}{c}\text { Filaments } \\
\text { per mm } \\
\text { length }\end{array}$ \\
\hline O. hupensis.......... & 4 & 5.7 & 49 & 8.6 \\
\hline O. formosana. & 7 & 5.1 & 49 & 9.6 \\
\hline O. nosophora... & 7 & 6.4 & 54 & 8.4 \\
\hline “ & 1 & 4.5 & 34 & 7.5 \\
\hline$“$ & 1 & 3.4 & 32 & 9.3 \\
\hline “ & 2 & 2.3 & 29 & 12.6 \\
\hline o. quadrasi. & 8 & 4.6 & 42 & 9.1 \\
\hline 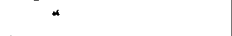 & 2 & 1.6 & 22 & 13.5 \\
\hline P. lapidaria... & 5 & 6.0 & 25 & 4.2 \\
\hline P. rincinnatiensis. & 5 & 5.5 & 17 & 3.1 \\
\hline 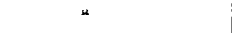 & 7 & 4.5 & 15 & 3.3 \\
\hline “ & 20 & 3.5 & 14 & 4.1 \\
\hline 4 & 11 & 2.5 & 14 & 5.6 \\
\hline 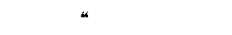 & 1 & 1.5 & 9 & 6.0 \\
\hline
\end{tabular}

All species of Oncomelania have a larger number of gills than the 2 species of Pomatiopsis studied. O. quadrasi and $O$. nosophora, of which young were available for study, appear to have a relatively smaller gill system in the adults than in the young, as was also observed in $P$. cincinna tiensis. Since the young of these 2 species are known to live in water, an increase in the importance of pulmonary respiration in the adults may be indicated. It was observed that $P$. lapidaria has a relatively small gill system, but it also shows a preference for more moist situations. Hence, a correlation does not appear to exist between the habitats of the various species and the development of pulmonary respiration.

\section{Discussion}

The 2 species of Pomatiopsis were characteristically more tolerant of low temperatures and less tolerant of high temperatures than were the 4 species of Oncomelania. P. lapidaria was less able to survive exposure to high temperatures than was $P$. cincinnatiensis. Although $P$. cincinnatiensis showed a more marked preference for a lower temperature than did $P$. lapidaria, it lives in a 
relatively exposed situation in nature and must frequently encounter high temperatures (when the sun shines on the bank), but usually only for short periods. $P$. lapidaria inhabits a more sheltered situation and normally would not be exposed to excessively high temperatures. During the winter $P$. cincinnatiensis hibernates (aestivates) under leaf litter or dormant grassy vegetation above the river banks (van der Schalie and Dundee 1955). The temperatures in such situations normally do not go much below freezing for extended periods. The seepage areas in which $P$. lapidaria occurs are normally frozen for extended periods during the winter. The moist soil and decaying vegetation freezes during the winter and, owing to the insulation of the dead vegetation covering the surface, remains frozen. The ability of $P$. lapidaria to withstand low temperatures better probably reflects the differences in temperatures in the habitats of these 2 species.

That the species of Oncomelania are less tolerant to low temperatures may be a reflection of the situations in which these species occur in nature; i.e., these animals are not subjected to extremely low temperatures. The relative ability of each of the 4 species to tolerate low temperatures corresponds to the range of latitude of their geographic distribution. O. nosophora and O. hupensis, the most northern species, are most tolerant to low temperatures, while $O$. quadrasi, from the Philippines, is the least; $O$. formosana, from Taiwan, is intermediate.

The degree of tolerance to high temperatures among the species of Oncomelania shows no such pattern. If one uses the same line of reasoning and considers the natural distribution pattern, $O$. quadrasi, the southern most species, should be most tolerant to high temperatures; however, it is less tolerant than either $O$. formosana or $O$. nosophora (data are not available for $O$. hupensis). Evidently, there must be modifying factors in the habitat of $O$. quadrasi so that it actually inhabits situations in which temperatures seldom go as high as those encountered by the more northern species. Its inability to tolerate extremes of temperature was also reflected in the experiments designed to permit these species to select the temperature preferred. $O$. quadrasi had the narrowest range of preference of any of the 6 species examined. It appears, therefore, that $O$. quadrasi lives in a habitat in which there is relatively little fluctuation of temperature and which is particularly shielded from high temperatures.

Pomatiopsis cincinnatiensis had the most restricted range of moisture preference; it also selected a drier substrate than the other 5 species.
Since it occupies the driest habitat of any of the species studied, one would anticipate such a preference as well as a tendency to be less able to withstand drowning and perhaps also to be better able to tolerate desiccation. The 2 former conclusions were shown to be true; however, the desiccation experiments indicated that this species was the most susceptible to drying, even more so than $O$. quadrasi, which, in nature, is found in an almost aquatic situation. It is evident, therefore, that $P$. cincinnatiensis requires a habitat which affords an optimum substrate moisture at all times. This animal cannot tolerate protracted fluctuations in moisture conditions. The river banks upon which it lives usually meet these requirements. Regardless of the degree to which the river fluctuates, there usually is a zone on the bank which has the proper moisture. Observations indicated that these snails move up the bank to avoid extended periods of flooding. Their inability to cope with conditions that lead to drowning, compared with $P$. lapidaria, also serves to emphasize some of the differences in the habitats of the 2 species of Pomatiopsis. Consequently, P. lapidaria, which inhabits low, marshy situations, can withstand extended periods of inundation, as shown by its resistance to drowning.

Among the species of Oncomelania, $O$ quadrasi, which was shown to prefer very moist situations, was most susceptible to desiccation. On the other hand, $O$. nosophora, which also lives in a moist situation, proved to be very tolerant of desiccation. This characteristic permits it to withstand extended periods of drying without appreciable mortality.

It has been established that the aquatic pulmonate snails which carry other human schistosome species are able to lose their infection under certain conditions of chilling or desiccation; the snails are thus rid of the parasite without being killed themselves. It would, therefore, be of interest to learn what influence the variations in tolerances of the amnicolid snails to ecological conditions have upon the $S$. japonicum parasites they carry. To a certain extent the parasites are undoubtedly adapted to the stresses of desiccation and variations in temperature. It seems possible that such an adaptation to the varying physiological environment within the Oncomelania species from different regions may account, in part, for the strain differences encountered in $S$. japonicum from different countries.

The Oncomelania used in the present study were, to the best of our knowledge, not parasitized. The reactions to the several factors, such as temperature, humidity, substrate moisture and desiccation were those of healthy, normal adults. 
Studies of tolerances of infected snails to factors in their environment would be of interest.

\section{SUMMARY}

A study was made of the temperature and moisture responses of the 2 American species of Pomatiopsis ( $P$. lapidaria and $P$. cincinnatiensis) and the 4 nominal Oriental species of Oncomelania (O. nosophora, O. formosana, O. quadrasi and $O$. hupensis).

When subjected to a temperature gradient ranging from $6^{\circ} \mathrm{C}$ to $36^{\circ} \mathrm{C}$, the mean temperatures preferred by the 6 species tested varied from $21^{\circ} \mathrm{C}$ for $P$. cincinnatiensis and $O$. hupensis to $26^{\circ} \mathrm{C}$ for $O$. quadrasi. The range of selection was between $12^{\circ} \mathrm{C}$ and $30^{\circ} \mathrm{C}$. When the animals were tested for their ability to tolerate low temperatures, i.e., a short exposure to extremely low conditions $\left(-5^{\circ} \mathrm{C}\right.$ and $\left.-7^{\circ} \mathrm{C}\right)$, the order of response from the least tolerant to the most was, as follows: (1) O. quadrasi; (2) O. formosana; (3) O. nosophora; (4) P. cincinnatiensis; and (5) P. lapidaria. All were killed by a 3-hour exposure to $-7^{\circ} \mathrm{C}$. In exposures to high temperatures $\left(34^{\circ} \mathrm{C}\right.$ to $48^{\circ} \mathrm{C}$ ) the onset of mortalities came between $41^{\circ} \mathrm{C}$ and $44^{\circ} \mathrm{C}$ with $P$. lapidaria least able to tolerate high temperatures; the remaining species were less tolerant in the following order: $P$. cincinnatiensis, $O$. quadrasi, $O$. nosophora and $O$. formosana. When the animals were exposed for longer periods to less extreme temperatures $\left(30^{\circ} \mathrm{C}\right.$ to $35^{\circ} \mathrm{C}$ ), both the Pomatiopsis species were quite sensitive with $P$. lapidaria slightly more so than $P$. cincinnatiensis; $O$. nosophora was much less tolerant than O. formosana; $O$. quadrasi was intermediate between the Pomatiopsis and the other Oncomelania.

Movement was studied in relation to temperature (at $5,10,15,20,25,30$, and $35^{\circ} \mathrm{C}$ ). In all species excepting one, little movement occurred before $20^{\circ} \mathrm{C}$ was reached; most movement occurred at $25^{\circ} \mathrm{C}$. The exception, $P$. cincinnatiensis, displayed considerable movement at temperatures as low as $10^{\circ} \mathrm{C}$ and it was still very active at $30^{\circ} \mathrm{C}$ and $35^{\circ} \mathrm{C}$. This adaptation is a necessity for a snail subject to wide extremes of temperature in the late fall when it must find its way to the top of the river bank where it hibernates.

To determine substrate moisture preference, a gradient ranging from 20 to approximately $100 \%$ of saturation was established. All the species avoided the region of the highest saturation; $P$. cincinnatiensis had the narrowest range of preference and tended to prefer a drier substrate.

The species of Pomatiopsis were less resistant to drowning than the Oncomelania; $P$. cincinnatiensis was less tolerant than $P$. lapidaria.

The order of toleration to desiccation, from the least to the greatest, was as follows: $P$. cincinnatiensis, $O$. quadrasi, $P$. lapidaria, $O$. formosana and O. nosophora. The male Oncomelania were more tolerant to desiccation than the females; no differences were observed among the sexes of Pomatiopsis.

Movement of the 6 species was measured through a range of 5 relative humidities $(95,85$, 75,65 , and $25 \%$ ) at $26^{\circ} \mathrm{C}$. Three species $(O$. nosophora, $O$. quadrasi and $P$. lapidaria) were less tolerant of the lower humidities, while $P$. cincinnatiensis, $O$. hupensis and $O$. formosana remained active in the lowest range tested.

\section{ACKNOWLEDGMENTS}

In order to carry out a program involving comparisons of Oriental snail species with related forms in Michigan, it was necessary to have stocks of the foreign species sent to us. It was both helpful and encouraging to receive assistance in obtaining stocks from staff in the following centers: Mr. James Williams of the Medical General Laboratory (406) in Japan (supplied Oncomelania nosophora) ; Dr. Robert E. Kuntz of the U. S. Naval Medical Research Unit No. 2 (supplied Oncomelania formosana); and Mr. Bonifacio C. Dazo and Mr. Ricardo Moreno, members of the W.H.O. Philippine 9 team (supplied Oncomelania quadrasi). In the course of the work, $\mathrm{Mr}$. Dazo gave generously of his expert assistance in maintaining and culturing these stocks. Mrs. Anne Gismann assisted in the preparation of the manuscript; Mrs. Stanlee Lonsdale drew the graphs. This work would not have been possible without the assistance of each of them; we are grateful for their interest and help.

\section{REFERENCES}

Abbott, R. T. 1948. A potential snail host of oriental schistosomiasis in North America (Pomatiopsis lapidaria). Proc. U. S. Nat. Mus. 98 (3222) : 57-68.

Berry, E. G. 1943. The Amnicolidae of Michigan: distribution, ecology, and taxonomy. Misc. Publ. Mus. Zool., Univ. Mich., No. 57.

and R. E. Rue. 1948. Pomatiopsis lapidaria (Say) an American intermediate host for Schistosoma japonicum J. Paras. suppl. 34: 15.

Dundee, D. S. 1957. Aspects of the biology of Pomatiopsis lapidaria (Say) (Mollusca: Gastropoda: Prosobranchia). Mus. Zool. Univ. Mich., Misc. Publ. 100: 1-37.

Getz, L. I. 1959. Notes on the ecology of slugs: Arion circumscriptus, Deroceras reticulatum and $D$. laeve. Amer. Midl. Nat. 61: 485-498.

Stunkard, H. W. 1946. Possible snail hosts of human schistosomes in the United States. J. Paras. 32: 539560 .

van der Schalie, H. and D. S. Dundee. 1955. The distribution, ecology and life history of Pomatiopsis cincinnatiensis (Lea), an amphibious, operculate snail. Trans. Amer. Micr. Soc. 74: 119-133.

- 1956. The morphology of Pomatiopsis cincinna- 
tiensis (Lea), an amphibious prosobranch snail. Occ. Papers Mus. Zool., Univ. Mich., No. 579.

- 1959. Transect distribution of eggs of Pomatiopsis lapidaria Say, an amphibious prosobranch snail. Trans. Amer. Micr. Soc. 78: 409-420.

- and L. L. Getz. 1961. Comparisons of adult and young Pomatiopsis cincinnatiensis (Lea) in respect to moisture requirements. Trans. Amer. Micr. Soc. 80: 211-220.

- (in Press) Distribution and natural history of Pomatiopsis cincinnatiensis. Amer. Midl. Nat.

- and H. J. Walter. 1957. The egg-laying habits of Pomatiopsis cincinnatiensis (Lea). Trans. Amer. Micr. Soc. 74: 404-422.

\title{
SOME PHASES OF THE LIFE HISTORY OF THE TROUT-PERCH ${ }^{1}$
}

\author{
John J. Magnuson ${ }^{2}$ and Lloyd L. Smith, Jr. \\ Department of Entomology, Fisheries and Wildlife, University of Minnesota, St. Paul
}

\section{INTRODUCTION}

The trout-perch, Percopsis omiscomaycus (Walbaum), is one of the more abundant forage fishes in the larger lakès of midwestern United States and central Canada where walleye, Stizostedion v. vitreum (Mitchill), yellow perch, Perca flavescens (Mitchill), and coregonids predominate. It has been suggested that it may have considerable effect on perch and walleye populations of these lakes. The present study describes growth, food habits, population structure, year-class strengths, and reproductive capacity of the trout-perch in relation to its population dynamics in lower Red Lake, Minnesota. The physical characteristics of Red Lake and the ecology of commercial species are described by Smith and Krefting (1954), Pycha and Smith (1955), Van Oosten and Deason (1957), and Smith and Pycha (1961).

Lower Red Lake, located in Beltrami and Clearwater Counties in north-central Minnesota (Figure 1) has an area of $255 \mathrm{mi}^{2}$ and a maximum

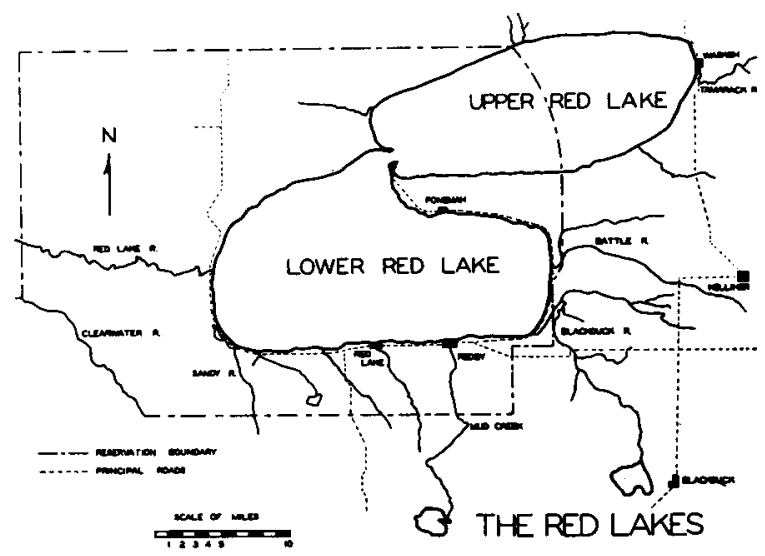

FIG. 1. The Red Lakes.

depth of $35 \mathrm{ft}$. The lake is isothermal, is subject to strong wind currents, and is moderately alkaline

${ }^{1}$ Paper No. 4749, Scientific Journal Series, Minnesota Agricultural Experiment Station, St. Paul 1, Minnesota.

${ }_{2}^{2}$ Present address: U. S. Bureau of Commercial Fisheries, P. O. Box 3830, Honolulu 12, Hawaii.
(130 to $160 \mathrm{ppm}$ ). There are no bays, and all shorelines are exposed to heavy wave action. Beaches are mostly sandy except in a few boulder areas along Ponemah Point and the south shore. The bottom soil is predominantly sand from shore to a depth of 17 to $20 \mathrm{ft}$ where it blends into an organic muck. Aquatic vegetation is absent in shallow water on the east shore, but the north, south, and west shores have bands of Scirpus sp. 50 to $100 \mathrm{ft}$ off the beaches. Outside of and mingled with the Scirpus, there are scattered beds of Potamogeton sp. The depth of water increases gradually with a steep drop-off occurring between the 8 - and 15 -ft contours. The 6 -ft contour is at least $600 \mathrm{ft}$ off the beach on most shorelines.

Trout-perch were sampled in June, July, and August, 1949-57. Quantitative samples consisted of 346 bag-seine hauls from the lake in August of 1955 and in the summers of 1956 and 1957 , 108 otter-trawl tows in 1956 and 1957; and 57 seine hauls from Mud Creek in 1956. From 1949 through 1954, 134 additional non-quantitative seine hauls were made. Shore samples were collected with 30- to 50-ft straight and bag seines $6 \mathrm{ft}$ deep with $\mathrm{r} / 4$-inch netting. After 1952 the 6 by 6 -ft bag was lined with fine netting (10 meshes to the inch). To collect fish in water 4 to $20 \mathrm{ft}$ in depth, a 10-ft otter trawl lined in the cod end with $\mathrm{r} / 8$-inch nylon bobbinet was towed at $3 \mathrm{mi} / \mathrm{hr}$. Four seining stations (Figure 1) were established on the south, east, west, and north shores of the lake. Trawling stations were outside the seining stations on the north, east, and south shores. Random subsamples of fishes were saved from the seine hauls and all forage fishes were saved from the trawl tows.

This study was supported in part by the U. S. Fish and Wildlife Service and the National Science Foundation.

\section{GrowTH}

Analysis of age and rate of growth was made from adult trout-perch taken on the beaches dur 